\title{
Smoothened Antagonist
}

National Cancer Institute

\section{Source}

National Cancer Institute. Smoothened Antagonist. NCI Thesaurus. Code C155725.

Any agent that is an antagonist at the Smoothened (SMO) receptor. 